\title{
PHYSICO-CHEMICAL PROPERTIES AND ENERGY POTENTIAL OF WOOD WASTES FROM SAWMILLS IN BENIN METROPOLIS, NIGERIA
}

\author{
E. P. Akhator ${ }^{1,}{ }^{*}$, A. I. Obanor ${ }^{2}$ and A. 0. Ugege ${ }^{3}$ \\ 1,2, 3 Department of Mechanical EngineERING, University of BEnin, BENin City, Edo State NiGERIA. \\ E-mailaddresses:13akhatorpeter@yahoo.com,2aiobanor@yahoo.com,3omoikeugege@yahoo.com
}

\begin{abstract}
The physico-chemical properties and energy potential of wood wastes were evaluated in this study. Wood wastes from five tropical species: Ekki (Lophira alata); Ohia (Celtis sp); Danta (Nesogordonia papaverifera); Omah (Cordia millenii) and Black Afara (Terminalia ivorensis) collected from sawmills across Benin Metropolis, the capital of Edo State, in South Western Nigeria were used as feedstock. Calorific values, moisture contents as well as proximate and ultimate analyses were performed to assess the energy characteristics of the collected wood wastes in accordance with the American Society for Testing and Materials: ASTM E872-82 and ASTM D4442-07. Results from the laboratory experiments and energy calculations revealed that the wood wastes used in this study contain relatively low moisture and ash contents, high proportions of volatile matter and carbon, high calorific values, low levels of sulphur and nitrogen as well as a sufficiently high value of thermal energy potential. The results are indications that the wood wastes are suitable as feedstock for renewable energy generation with little or no threat to the environment.
\end{abstract}

Keywords: Benin Metropolis; Bio-energy; Calorific value; Energy potential; Physico-chemical properties; Wood waste.

\section{INTRODUCTION}

Biomass as bio-energy sources has been cited as one of the world's largest renewable energy source and its resources are distributed around the world [1]. Biomass resources are considered renewable because they occur naturally and when properly managed, may be harvested without significant depletion. Although biomass can come from many different sources, wood is by far the most common [2]. In 2015, about $46 \%$ of renewable energy consumed in the European Union (EU) came from solid biomass (almost exclusively wood) [2]. In 2013, solid biomass accounted for 3\% of the electricity produced in the EU and 15\% of the heat produced in industrial sectors [2]. The use of woody biomass for energy generation can offset fuels such as coal, gasoline, natural gas and oil $[3,4]$. Such a practice can enhance economic development, foster new industries making bio-based products, and encourage green economy as well as energy independence. For example, in 2013, the European solid biomass and biogas sectors generated a turnover of about 42 billion Euro and employed over 300 thousand people [2].

In Nigeria, a West African country, around 11million hectares of forest and about 5.5million hectares of other wooded land are available [5]. Logging activities in the forests and wood processing at the various wood processing industries generate a huge volume of wood wastes annually across cities in the country. For example, about 294,798 tonnes of wood waste is generated yearly in the city of Lagos [6], Aina [7] estimated that about $2288 \mathrm{~m}^{3}$ of wood wastes are generated daily in Abeokuta, while Dosunmu and Ajayi [8] reported a figure for wood wastes from Nigerian sawmills to be about 5.2million tonnes per year. These quantities of wood wastes could be harnessed to produce electricity, heat and transportation fuels by using several technologies available such as direct combustion, gasification and pyrolysis [9]. Combustion with energy recovery involves the burning of wood wastes and transferring the heat produced to water for the purpose of generating steam in boiler super-heater tubes. The steam may be used to generate electricity in a steam turbine generator or sold directly for commercial or process heat purposes. Gasification converts wood waste into synthetic gas which can be utilized to produce steam in boiler superheater tubes, to generate electricity directly in an internal combustion (IC) engine or as transportation fuels. Pyrolysis converts wood waste into bio-oil and biochar from which energy and transportation fuels can be obtained. For such utilization, information on the basic physico-chemical properties of wood wastes is necessary to ascertain their suitability as feedstock [10]. It is worthy of note that the knowledge and application of wood wastes as an energy generation source in Nigeria is

\footnotetext{
* Corresponding author, tel: +234-818-514-4066
} 
still at a very low level compared to developed countries. While wood species such as spruce and willows on account of their energy content and properties are specially grown, and harnessed for energy generation in most parts of Europe, the same cannot be said of Nigeria as salient information on the type of wood species in the country for energy production are not known. Therefore, this study assessed the physico-chemical properties and energy potential of wood wastes from sawmills in Benin City, the capital of Edo State in South Western Nigeria. This is aimed at providing valuable information on energy characteristics of wood waste species in the City that will aid in formulating long term policies, and plan effective ways of exploiting and utilizing wood waste for energy generation.

\section{MATERIALS AND METHODS}

\subsection{Materials}

Wood waste from five tropical species were collected from sawmills across Benin Metropolis in South Western Nigeria and studied. The wood species were: Ekki (Lophira alata); Ohia (Celtis sp); Danta (Nesogordonia papaverifera); Omah (Cordia millenii) and Black Afara (Terminalia ivorensis) [11].

\subsection{Methods}

Wood processing activities were physically observed for 6 days/wk at the sawmills for 15 weeks. The dimensions of logs and the corresponding lumbers of the wood species of interest were measured using measuring tape of $15 \mathrm{~m}$ length and wood waste samples of the required species were collected for 8 hours each day. The wood waste samples collected were dried in air to reduce moisture content and prevent degradation by fungi. The samples were later oven dried at a temperature of $105^{\circ} \mathrm{C}$ until constant mass was achieved. The wood waste samples were ground and sieved to $2 \mathrm{~mm}$ particle sizes and experiments were carried out on each sample to determine their calorific values, moisture content as well as proximate and ultimate analyses. The experiments were conducted according to the American Society for Testing and Materials Standards ASTM E870-82[12] and ASTM D4442-07[13]. The volumes of logs of each wood species before conversion to lumbers and the volumes of the corresponding lumbers were determined using the dimensions measured during the survey. Thereafter, the volume of each wood waste sample was obtained by algebraic subtraction between the volumes of the respective logs and lumbers. Known densities of the wood species were used to estimate the mass of the wastes.

\subsubsection{Wood Waste Sample Calorific Value Determination}

A digital oxygen bomb calorimeter was used to determine the calorific value of the samples. Approximately $1.0 \mathrm{~g}$ of each sample was weighed out and carefully placed in the sample cup of the calorimeter using tweezers. Approximately $10 \mathrm{~cm}$ of nickel fuse wire, of known weight, was measured out and attached to the electrodes. The sample cup was placed in the cup holder and the fuse wire was positioned in such a way that it almost touched the surface of the sample. The bomb was then carefully charged with oxygen gas to a pressure of about 30atm before being ignited. In this study, each experiment was repeated twice. The calorific value (CV) of the samples was calculated afterwards using equation 1 [14].

$$
\mathrm{CV}=\frac{C \Delta T-(e 1+\mathrm{e} 2+\mathrm{e} 3)}{\mathrm{m}}
$$

In (1), CV is calorific value (MJ/kg), C is heat capacity of bomb calorimeter, $\Delta \mathrm{T}$ is change in temperature, $\mathrm{m}$ is mass of sample (g), e1, e2 and e3 are corrections for formation of nitric acid, sulphuric acid and fuse wire, respectively.

\subsubsection{Proximate and Ultimate Analyses}

Proximate and ultimate analyses were carried out following the procedure of ASTM E870-82. Proximate analysis was done to determine physico-chemical properties like percentage volatile matter, percentage ash content and percentage fixed carbon in each sample. Percentage fixed carbon content was obtained by difference of the sum on percentage volatile matter and ash content. Ultimate analysis was carried out to determine the percentages of carbon, hydrogen, nitrogen, sulphur and oxygen in each sample. Percentage oxygen was obtained by difference of the sum of carbon, hydrogen, nitrogen and sulphur contents.

\subsubsection{Moisture Content}

The change in weight of each wood waste sample after oven drying was used to determine their moisture content using equation 2

$$
\% M C=\frac{M_{d}}{M_{d}} \times 100
$$

In (2), MC is moisture content, $M_{d .}$ is change in mass and $\mathrm{M}_{\mathrm{s}}$ is mass of sample (g).

\subsubsection{Thermal Energy Potential}

This is the actual amount of thermal energy present in each wood waste sample per unit time. It was calculated using equation 3

$$
\text { T.E.P }=\rho \times V \times C V
$$

In (3), T. E. P is energy potential $\left(\mathrm{kW}_{\mathrm{th}}\right), \rho$ is the density

$\left(\mathrm{kg} / \mathrm{m}^{3}\right), \mathrm{V}$ is the rate of wood waste collected per unit time $\left(\mathrm{m}^{3} / \mathrm{s}\right)$. 
A conversion efficiency of $32 \%$ [15] was assumed to convert the thermal energy potential to electrical power in $\mathrm{kW}_{\mathrm{el}}$. This implies that $1 \mathrm{~kW}_{\mathrm{el}}$ is numerically equal to $0.32 \mathrm{~kW}$ th.

\section{RESULTS AND DISCUSSION}

The proximate analysis of the wood waste samples are presented in Table 1

Table 1: Proximate analyses of wood waste samples

\begin{tabular}{llll}
\hline Wood species & $\begin{array}{l}\text { VM } \\
\text { \%ts }\end{array}$ & $\begin{array}{l}\text { Ash } \\
\text { \%ts }\end{array}$ & $\begin{array}{l}\text { \%Fixed } \\
\text { carbon }\end{array}$ \\
\hline Lophira alata & 71.01 & 1.81 & 27.18 \\
Celtis sp & 77.08 & 0.79 & 22.13 \\
Nesogordonia & 87.70 & 2.45 & 9.85 \\
papaverifera & 79.75 & 2.56 & 17.69 \\
Cordia millenii & 87.43 & 3.81 & 8.76 \\
Terminalia ivorensis & & & \\
\hline
\end{tabular}

Table 2: Calorific values and moisture content of wood waste samples.

\begin{tabular}{lll}
\hline Wood species & $\begin{array}{l}\text { Calorific value } \\
(\mathrm{MJ} / \mathrm{kg})\end{array}$ & $\begin{array}{l}\text { \%MC }(\text { oven } \\
\left.\text { dried, } 105^{\circ} \mathrm{C}\right)\end{array}$ \\
\hline Lophira alata & 19.45 & 10.12 \\
Celtis sp & 19.81 & 12.38 \\
Nesogordonia & 19.56 & 13.34 \\
papaverifera & 19.78 & 9.84 \\
$\begin{array}{l}\text { Cordia millenii } \\
\text { Terminalia } \\
\text { ivorensis }\end{array}$ & 20.15 & 9.52 \\
\hline
\end{tabular}

Table 3: Ultimate analysis of wood waste samples on percentage dry weight.

\begin{tabular}{lccccc}
\hline Wood species & Carbon & Hydrogen & Oxygen & Nitrogen & Sulphur \\
\hline Lophira alata & 56.45 & 5.59 & 37.75 & 0.15 & 0.06 \\
Celtis sp & 55.35 & 5.33 & 39.11 & 0.15 & 0.06 \\
Nesogordonia & 57.24 & 5.16 & 37.43 & 0.14 & 0.03 \\
papaverifera & 58.92 & 5.1 & 35.8 & 0.11 & 0.07 \\
Cordia millenii & 58.9 & & \\
Terminalia & 57.57 & 5.3 & 36.98 & 0.11 & 0.04 \\
ivorensis & & & & & \\
\hline
\end{tabular}

Volatile matter strongly influences thermal decomposition and combustion behaviour of solid fuels $[16,17]$. Table 1 shows that the percentage volatile matter ranged from 71.01 to $87.70 \%$, with Nesogordonia papaverifera having the highest value while Lophira alata has the lowest value. The higher the proportion of volatile matter, the more suitable is the wood waste specie for thermal conversion $[18,19]$. Ash which is the non-combustible component of solid fuels was shown to range from 0.79 to $3.81 \%$, this low ash content is a desirable factor when utilizing fuel wood for energy generation. Loo and Koppejan [17] reported that the higher the ash content in a fuel the lower its heating value. Table 1 also reveals that the percentage fixed carbon obtained for the wood species ranged from 9.85 to $27.18 \%$, with Lophira alata having the highest value while Terminalia ivorensis has the lowest value. Similar ranges of percentage volatile matter, ash content and fixed carbon have been reported for several wood species by Akinola and Fapetu [20].

The results shown in Table 1 indicate that these wood wastes will have ease of ignition and stable flame during combustion as well as high heating value. Table 2 shows the calorific values and moisture content of each wood waste sample.

Results from the study revealed a calorific value ranging from 19.45 to $20.15 \mathrm{MJ} / \mathrm{kg}$ as shown in Table 2. The results indicate good energy content and agree with findings of Huhtinen [21], who reported that the calorific values of wood species ranges between 18.5 to $21.0 \mathrm{MJ} / \mathrm{kg}$, and that calorific value of wood does not vary much from one species to another. Table 2also shows that the moisture content of the wood wastes ranged from 9.52 to $13.34 \%$. This relatively low moisture content favours thermo-chemical conversion since high moisture content reduces the efficiency of the conversion systems [21, 22], and also reduces the energy available from wood wastes during combustion, as heat would be required to vaporize it[23].

Table 3 shows the results of the ultimate analysis of the wood waste samples on percentage dry weight basis. Table 3 reveals that each of the samples has carbon content higher than any other element. High carbon content is expected to increase the calorific value of the wood wastes. The carbon values ranging from 55.35 to $58.92 \%$ agrees with findings of Fapetu [9], who reported a carbon content range for wood biomass to be in the range of $50-60 \%$.Table 3 also reveals high percentage of hydrogen and oxygen, indicating high energy potential of the wood wastes. Carbon, hydrogen and oxygen are the major components of biomass feedstock and the main reactants during combustion processes [24]. It can be seen in Table 3 that all the wood species contained low levels of nitrogen and sulphur as required by the DIN 51731 [25]. These imply that very low levels of $\mathrm{NO}_{\mathrm{x}}$ and $\mathrm{SO}_{\mathrm{x}}$ will be emitted if the wood wastes are used in thermal conversion processes.

Table 4 shows the density, quantity and energy potential of each wood waste samples. The densities of the wood waste samples were obtained from Carsan et al. [26]. The volume of each wood waste specie presented in Table 4 is the total quantity collected during the survey period. Table 4 also presents the energy potential of the sampled wood waste species based on the volume collected over the survey period, with Celtis sp and Cordia millenii having the highest and lowest energy potential respectively. 
Table 4: Density, quantity and energy potential of wood waste samples.

\begin{tabular}{|c|c|c|c|c|c|}
\hline Wood species & $\begin{array}{l}\text { Wood } \\
\text { waste } \\
\text { density } \\
\left(\mathrm{kg} / \mathrm{m}^{3}\right)\end{array}$ & $\begin{array}{c}\text { Wood } \\
\text { waste } \\
\text { volume } \\
\left(\mathrm{m}^{3}\right)\end{array}$ & $\begin{array}{l}\text { Wood } \\
\text { waste } \\
\text { mass } \\
\text { (tons) }\end{array}$ & $\begin{array}{l}\text { Thermal } \\
\text { energy } \\
\text { potential } \\
\left(\mathrm{kW}_{\mathrm{th}}\right) \mathrm{I}^{-2}\end{array}$ & $\begin{array}{l}\text { Electrical } \\
\text { power } \\
\left(\mathrm{kW}_{\mathrm{el}}\right) \\
10^{-3}\end{array}$ \\
\hline Lophira alata & 1080 & 4.25 & 4.59 & 3.444 & 11.022 \\
\hline Celtis sp & 725 & 12.15 & 8.81 & 6.732 & 21.543 \\
\hline Nesogordonia papaverifera & 765 & 5.47 & 4.18 & 3.158 & 10.105 \\
\hline Cordia millenii & 550 & 5.01 & 2.76 & 2.103 & 6.729 \\
\hline Terminalia ivorensis & 560 & 6.13 & 3.43 & 2.669 & 8.540 \\
\hline
\end{tabular}

This indicates that wood wastes can be viable resources for electricity generation in Benin metropolis and Nigeria at large. The utilization of wood waste in Nigeria for electricity generation would not only complement that available from the national grid, but will also boost economic activities and assist in the effort to enhance its management. Such wood waste utilization would also contribute to achieving the goals of Nigeria's Renewable Energy Master Plan (REMP), which is to have biomassbased power plants with installed capacity of $50 \mathrm{MW}$ in 2015 and 400MW in 2025 [27].

\section{CONCLUSION}

This study assessed the physico-chemical properties and energy potential of wood wastes from sawmills in Benin metropolis. The results indicated that wood wastes from Benin metropolis are suitable as feedstock to generate electricity through thermo-chemical conversion processes. The study revealed that the wood waste species sampled had a calorific value ranging from 19.45 to $20.15 \mathrm{MJ} / \mathrm{kg}$ and a thermal energy potential ranging from 2.103 to $6.732 \mathrm{~kW}_{\text {th }}$, implying that wood wastes from sawmills in Benin metropolis could be utilized for electricity generation in Nigeria.

\section{ACKNOWLEDGEMENTS}

We are grateful to the Forestry Division, Edo State Ministry of Environment and Public Utilities for providing useful data on sawmills located in Benin metropolis. We are equally thankful to the National Centre for Energy Research and Development (NCERD), University of Nigeria, Nsukka for allowing the use of their laboratory and equipment.

\section{REFERENCES}

[1] Antonia, V. H., Timothy, E. L. and Daniel, M. K. "Renewable energy sources". www.eolss.com, Accessed July 5, 2016

[2] Bourguignon, D. "Biomass for electricity and heating: opportunities and challenges", 2015. http://www.europarl.europa.eu/ Reg. Data/etudes/ BRIE/2015/568329/ EPRS
BRI(2015) 568329EN.pdf, Assessed September 25, 2016.

[3] Baskar , C., Baskar, S., Dhillon, R. S. Biomass Conversion: The Interface of Biotechnology, Chemistry and Materials Science, Springer, Berlin, Germany, 2012.

[4] Richard, L. B., Kelvin, C. C., Ralph, P. O. Biomass gasification-commercialization

and development: The combined heat and power (CHP) option. National Renewable Energy Laboratory, USA, 2002.

[5] The Food and Agriculture Organization (FAO) of the United Nations." Global Forest Resources Assessment".http://www.fao.org/docrep/008/a04 00e/a0400e00.HTM,Assessed August 5, 2016.

[6] United State Department of Agriculture. "Wood Handbook: Wood as an Engineering Material". General Technical Report FPL-GTR-190, 2010 Madison, U.S.A, https://www.arb.ca.gov/regact/2014/capandtrade prf14/usfswoodhandbook2010.pdf, Accessed October 26, 2016.

[7] Aina, 0. M. Wood Waste Utilization for Energy Generation. Proceedings of the International Conference on Renewable Energy for Developing Countries, 2006, http://cere.udc.edu/Aina.pdf, Accessed October 21, 2016.

[8] Dosunmu, 0. O. and Ajayi, A. B. Problems and management of sawmill waste in Lagos. Proceedings of International Symposium on Environmental Pollution Controand Waste Management, January 7-10, Tunis, (EPCOWM'2002), pp.271-278. 2002.

[9] Fapetu, O. P. "Management of energy from biomass. Nigerian Journal of Engineering Management, Vol. 1, Number 1, pp 14-19. 2000.

[10] Oladeji, J. T. "Fuel characterization of briquettes produced from corncob and rice husk residues", Pacific Journal of Science and Technology, Vol. 1, Number 1, pp 101-106. 2010,

[11] Kalu, C., Atagan, S., Ani, P. I. "Marketing of round wood in Benin City, Edo State, Nigeria", Journal of Applied Sciences Research, Vol. 5, Number 7, pp 785-789. 2009. 
[12] ASTM E870-82. Standard test method for analysis of wood fuels, ASTM International, West Conshohocken, PA, 2013, www.astm.org.

[13] ASTM D4442-07. "Standard Test Methods for Direct Moisture Content Measurement of Wood and Wood-Base "ASTM International, West Conshohocken, PA, 2013, www.astm.org. 2007.

[14] Parr Instrument Company. "1356 Isoperibol Bomb Calorimeter". www.parrinst.com/wpcontent/uploads/downloads/2011/07/434M parr 1356-Calorimeter-Service-Manual.pdfAssessed August 15, 2016.

[15] International Energy Agency, "Biomass for power generation and CHP". https://www.iea.org/publications/freepublications /publication/essentials3.pdf Accessed September 20, 2016. 2007.

[16] Olsson, M., Kjallstrand, J. and Peterson, G. "Oxidative pyrolysis of integral softwood pellets", Journal of Analytical and Applied Pyrolysis Vol. 67, 2003, pp 135-141.

[17] Loo, S. V. and Koppejan, J. The Handbook of Biomass Combustion and Co-firing. Earthscan, 2008.

[18] Olsson, M, Ramas, O. and Peterson, G. "Specific volatile hydrocarbons in smoke from oxidative pyrolysis of softwood pellets", Journal of Analytical and Applied Pyrolysis Vol. 71, pp 847-854. 2004.

[19] Holt, G. A., Blodgett, T. L. and Nakayam, F. S. "Physical and combustion characteristics of pellet fuel from cotton gin by-products produced by select processing treatment", Industrial. Crops and Products Vol. 24, pp 204-213. 2006.

[20] Akinola, O. A. and Fapetu, O. P. "Characteristics study of wood wastes from sawmills", British
Journal of Applied Science \& Technology, Vol. 6, Number 6, pp 606-612. 2015.

[21] Huhtinen M. "Wood energy: wood as a fuel". Materials for 5EURES Training Sessions; NCP, Finland, 2009, file://M/5Eures/WoodPropertiesPDF.htm, Accessed August 15, 2016.

[22] Brammer, I. G., Bridgwater, A. V. "The influence of feedstock drying on the performance and economics of a biomass gasifier - engine CHP System". Biomass and Bioenergy, Vol. 22, pp 271281. 2002.

[23] Yang, Y. B., Ryu, C., Khor, A., Yates, N. E., Sharifi, V. N. and Swithen bank, J. "Effect of fuel properties on biomass combustion, part II", Fuel, vol. 84, pp 2116-2130. 2005.

[24] Sha fizad eh F. 1984. "The chemistry of pyrolysis and combustion-the chemistry of solid wood", Pp. 489-529 in Rowell, RM (ed) Advances in Chemistry Series Number 207. American Chemical Society, Washington DC.

[25] DIN 51731. Testing of solid fuels-compressed untreated wood, requirements and testing. Deutsches Institute fur Normung, Berlin, 1996.

[26] Carsan, S., Orwa, C., Harwood, C., Kindt, R., Stroebel, A., Neufeldt, H., Jamnadass, R. "African Wood Density Database". World Agroforestry Center, Nairobi, www.worldagroforestry.org/treesnmarkets/wood/ data.php?id=8\#Assessed July 15, 2016. 2012.

[27] International Energy Agency, "Nigeria Renewable Energy Master Plan". www.iea.org/policiesandmeasures/pams/nigeria/ name-24808-en.php? Assessed August 5, 2016. 2011. 